\title{
FAKTOR YANG BERHUBUNGAN DENGAN PERILAKU PERAWAT DALAM PEMAKAIAN APD DI RUANG RAWAT INAP SALAH SATU RUMAH SAKIT SWASTA DI YOGYAKARTA
}

\author{
V.Endah Mawarni ${ }^{1}$, Ch. Setya Widyastuti ${ }^{2}$, Eva Marti ${ }^{3}$ \\ ${ }^{1}$ STIKes Panti Rapih Yogyakarta, Jl. Tantular No 401, Condongcatur, Depok, Sleman, \\ Yogyakarta, email: stikespr@stikespantirapih.ac.id. \\ ${ }^{2}$ STIKes Panti Rapih Yogyakarta, Jl. Tantular No 401, Condongcatur, Depok, Sleman, \\ Yogyakarta, email: chatarinasw@stikespantirapih.ac.id@stikespantirapih.ac.id. \\ ${ }^{3}$ STIKes Panti Rapih Yogyakarta, Jl. Tantular No 401, Condongcatur, Depok, Sleman, \\ Yogyakarta,email: eva_marti@stikespantirapih.ac.id@stikespantirapih.ac.id.
}

\begin{abstract}
ABSTRAK
Latar Belakang: Perilaku perawat dalam pemakaian APD di pandang sangat pentingdalam meningkatkan mutu pelayanan kesehatan serta keselamatan dan kesehatan kerja perawat di rumah sakit.
\end{abstract}

Tujuan: Untuk mengetahui faktor-faktor yang berhubungan dengan perilaku perawat dalam pemakaian alat perlindungan diri diunit Rawat Inap salah satu Rumah Sakit Swasta di Yogyakarta.

Metode: Penelitian ini menggunakan desain penelitian deskriptif kuantitatif dengan pendekatan cross sectional, dengan jumlah sampel sebanyak 30 responden.Sampel yang diperoleh dengan teknik total populasi. Metode pengumpulan data yang digunakan yaitu kuesioner dan observasi.

Hasil: Penelitian menunjukkan sebagian besar perawat perilaku cukup baik 63,3\%, hampir setengahnya perilaku baik 33,3\% dan sebagian kecil perilaku kurang baik 3,3\%. Sebesar 70\% memiliki pengetahuan baik, sebagian kecil pengetahuan cukup baik 13,3\% dan sebagian kecil pengetahuan kurang baik 16,7\%. Sebagian besar sikap cukup positip 53,3\%, hampir setangah nya sikap positip $40 \%$ dan sebagian kecil sikap negative $6,7 \%$. 
Faktor yang Berhubungan dengan Perilaku Perawat dalam Pemakaian APD di Ruang

Rawat Inap Salah Satu Rumah Sakit Swasta di Yogyakarta

Simpulan: Diharapkan Rumah Sakit memberikan sosialisasi dan praktik pemakaian APD oleh PPI kepada perawat ruang rawat inap setiap 3 bulan sekali dan meningkatkan kesadaran serta saling mengingatkan sesama perawat untuk memakai APD sesuai SPO.

Katakunci: Pengetahuan, sikap, ketrampilan, perilaku, APD.

\section{ABSTRACT}

Backround: Nurses' behavior in using PPE is considered very important in improvingthe quality of health services as well as the occupational safety and health of nurses inhospitals

Objective: To determine the factors related to the behavior of nurses in nusing personal protective equipment in the inpatient unit Private Hospital at Yogyakarta.

Methods: This study used a quantitative descriptive research design with a cross sectional approach, with a total sample of 30 respondents. The sample obtained by the total population technique. The data collection methods used were questionnaires and observations.

Results: The study showed that most of the nurses had good enough behavior, $63,3 \%$, almost half of them had good behavior, 33,3\% and a small proportion of bad behaviorwas 3,3\%. As much as 70\% have good knowledge, a small proportion of knowledge isgood enough, 13,3\% and a small proportion of knowledge is not good $16,7 \%$. Most ofthe attitudes are quite positive 53,3\%, almost half are positive attitudes are $40 \%$ and a small have negative attitudes $6,7 \%$.

Conclusion: It is hoped that the hospital will provide socialization and practice of usingPPI by PPI to inpatient room nurses once every 3 months and raise awareness and remind fellow nurses to wear PPE according to the SPO.

Keywords: Knowledge, attitudes, skills, behavior, PPE. 


\section{PENDAHULUAN}

RumahSakit merupakantempat kerjayangmemiliki resikotinggi terhadapkeselamatandan kesehatan sumber dayamanusia rumah sakit, pasien,pengujung maupunlingkungan rumah sakitsebagai institusipelayanan kesehatanbagi masyarakat.Hal ini ditetapkan dalam Peraturan Menteri Kesehatan Nomor66 Tahun 2016 tentang Keselamatan dan Kesehatan Kerja RumahSakit. Resiko Infeksiyang harus diwaspadaidirumah sakitsaatini yaitu Corona Virus Desease (COVID-19) yang merupakan penyakit pernafasanakutdisebabkanoleh virus corona yangbernamasevere acute respiratory syndrome coronavirus 2 atauSARS CoV-2(Gorbalenyaet al.,2020dalamTheopilus, Thedy, Theresia,\& Octavia,2020). World Health Organization (WHO) melaporkan ada lebih dari 22.000 petugas medis tersebar di52negaradan wilayah dinyatakan telah terinfeksi virus corona(Covid-19)danwilayah dinyatakan telah terinfeksiviruscorona. Petugas tersebutdiketahui terinfeksi ketikamerawat dan menangani pasien dalam keadaan
perlindungandiri.Di Indonesiajumlah tenagamedisyagterinfeksi,sebesar234 petugas kesehatan. Menurutdata yang dihimpun olehPersatuanPerawat Nasional Indonesia(PPNI)jumlah kematian perawat pada bulan maret 2020 sebanyak 85 perawat ( Lubis, 2020).

Upaya Rumah Sakit untuk melindungi petugas kesehatan terutama perawat dan pasien dari resiko tertular penyakit infeksi tersebut maka dilakukan dalam bentuk universal precaution. Menurut Nursalam dan Ninuk (2011) yang disitasi oleh Puspitasari (2019) salah satu komponen universal precaution adalah penggunaan Alat Perlindungan Diri (APD) seperti sarung tangan, masker, kacamata pelindung dan apron. Beberapa jenis APD yang diwajibkan untuk melindugi diri dan mencegah penularan Corona Virus Desease (COVID-19) yaitu masker, pelindung wajah, sarung tangan, hal ini digunakan untuk mencegah penularan Covid-19 (Theopilus, Yogasara, Theresia \& Octavia 2020). Sesuai dengan Kemenkes RI (2020), APD adalah perangkat alat yang dirancang sebagai penghalang terhadap penetrasi zat, partikel padat, cair atau udara untuk melindungi pemakainya dari cedera atau penyebaran infeksi atau penyakit. Setiap petugas 
Faktor yang Berhubungan dengan Perilaku Perawat dalam Pemakaian APD di Ruang Rawat Inap Salah Satu Rumah Sakit Swasta di Yogyakarta

kesehatan harus mengetahui cara yang tepat untuk mengenakan dan melepas (doffing) APD. Setiap kesalahan dalam melakukan hal tersebut dapat membuat individu terkena agen infeksi. APD mampu mencegah segala invasi partikel virus ke dalam system seseorang (Mahmood, Crimbly, Khan, Choundry \& Mehwis, 2020).

Faktor - faktor yang berhubungan dengan perilaku perawat dalam pemakaian APD dipandang sangat penting dalam usaha pencegahan dan pengendalian infeksi serta dapat meningkatkan mutu pelayanan kesehatan. Perilaku pemakaian APD menurut teori Lawrence Green menjelaskan bahwa perilaku itu sendiri ditentukan atau terbentuk dari tiga faktor, yaitu factor presdiposisi (presdiposing factors), yangterwujud dalam pengetahuan, sikap, kepercayaan, keyakinan, nilai dan sebagainya. Faktor-Faktor pendukung (enabling factors), yang terwujud dalam lingkungan fisik, tersedia atau tidak tersedianya fasilitas- fasilitas atausaranasaranakesehatan. Faktorfaktorpendorong (reinforcing factors) yang terwujuddalamsikapdan perilaku petugas kesehatan atau petugas lain yang merupakan kelompok referensi dari perilaku masyarakat dilakukanpenelitiandi Rumahsakit Santa Elisabeth,darihasilobservasidan wawancara pada tanggal 20-25 September 2020kepada12orang perawat, kami menemukandari data Pencegahan dan Pengendalian Infeksi (PPI)bahwajumlah kecelakaantertusuk jarum pada perawat tahun 2019 sebanyak5 kasus, dataplebitis bulan Januari 2020 ada 6,7\% dan Agustus 2020ada 2,9\%o.Kepatuhanpemakaian APD perawat dirawat inap tinggi sebesar97,8\%.Penilaianini didapatkan dari hasilpemantauan ceklisperawat yang memakai APD danperawatyang tidak memakaiAPD dan tidakberdasar pemantauan kualitaspemakaianya. Perawat mengatakanada perubahan APD selama pandemiyaitu penggunaan topi, masker,gaunpelindungdanface shield. Perawat tidak menggantisarung tangan saat melakukan tindakan vital sign, pemberianobat injeksi dan morningcare yangberbedakepasien lain. Perawatmengangkattelepon dan mengambilalat tenunbersih saat memakaisarungtangan yangsudah terkontaminasi,perawat tidak 
menggunakan maskerdengan benar, Rancangan penelitian yang digunakan (lubang hidung masih terlihat). Dari dengan pendekatan crosssectional. Pada data tersebutdapatdilihatperilaku penelitian ini peneliti akan mengambil pemakaian APD perawatberdasarkan data varia belterikat (dependen) yaitu risiko penularan yang semakin tinggi perilaku perawat dalam pemakaian APD danpentingnyaperilaku kualitas dalam pemakaianAPD.Darilatar belakang tersebut maka perlu melakukan penelitian terkaitfaktorpengetahuan, sikap, ketrampilanyangberhubungan denganperilakuperawat dalam pemakaianAPDdi RuangRawatInap RumahSakit SantaElisabeth sejumlah 30 responden. Proses pengumpulan data dimulai pada tanggal 11 Januari 2021

Sampai dengan 10 Februari 2021 dengan kuesioner pengetahuan perilaku, sikap melalui google form dan lembar ceklist observasi ketrampilan dan perilaku. Analisis data dengan analisis univariat untuk melihat distribusi frekuensi variabel dependent dan Analisis bivariat dilakukan dua variabel yang berhubungan atau berkorelasi dengan menggunakan uji statistik Fisher.

\section{METODEPENELITIAN}

Penelitian yang digunakan adalah metode penelitian kuantitatif. Jenis penelitian deskriptif. dan variabel bebas (independen) yaitu pengetahuan, sikap, ketrampilan. Pengambilan sampel pada penelitian ini menggunakan total populasi yaitu semua perawat yang bekerja diruang rawat inap salah satu Rumah Sakit Swasta di Yogyakarta

\section{HASILDANPEMBAHASAN}

Tabel 1

Distribusi Frekuensi Karakteristik

\begin{tabular}{ccc}
\multicolumn{2}{c}{ DataResponden } \\
\hline Karakteristik & $\begin{array}{c}\text { Fre } \\
\text { kuensi }\end{array}$ & $\begin{array}{c}\text { Prese } \\
\text { ntasi }\end{array}$
\end{tabular}

$(\%)$

\begin{tabular}{lcc}
\hline Jenis Kelamin & & \\
Perempuan & 26 & 86,7 \\
Laki-laki & 4 & 13,3 \\
\hline Pendidikan & & \\
DIII Keperawatan & 29 & 96,7 \\
S1 Keperawatan & 1 & 3,3 \\
\hline Umur & & \\
$21-30$ & 19 & 63,3 \\
$31-40$ & 2 & 23,3 \\
$41-50$ & 2 & 6,7 \\
$51-60$ & 2 & 6,7 \\
& & \\
\hline Masa kerja & & \\
$\mathbf{1 - 5}$ & 19 & 63,3 \\
$\mathbf{6 - 1 0}$ & 8 & 26,7 \\
$\mathbf{1 1 - 1 5}$ & 0 & 0 \\
$\mathbf{1 6 - 2 0}$ & 0 & 0 \\
$\mathbf{3 1 - 2 5}$ & 0 & 0 \\
$\mathbf{2 6 - 3 0}$ & 3 & 10 \\
& & \\
\hline er:Data primer & &
\end{tabular}

Berdasarkan karakteristik responden jenis kelamin didukung penelitian 
Faktor yang Berhubungan dengan Perilaku Perawat dalam Pemakaian APD di Ruang

Rawat Inap Salah Satu Rumah Sakit Swasta di Yogyakarta

Apriluana (2016) responden yang

Berjenis kelamin perempuan lebih banyak $76,1 \%$ yang berperilaku baik dalam penggunaan APD, dibandingkan berperilaku kurang23,9\%. Sedangkan laki-laki lebih banyak 78,8\% yang berperilaku baik dalam penggunaan APD dibandingkan berperilaku kurang $21,2 \%$

\section{Tabel2}

Distribusi Frekuensi Perilaku Perawat dalam Pemakaian APD di Unit Rawat Inap Salah Satu Rumah Sakit Swasta di Yogyakarta Februari 2021

\begin{tabular}{lcc}
\hline Perilaku & $\begin{array}{c}\text { Frekuensi } \\
(\mathrm{n})\end{array}$ & $\begin{array}{c}\text { Persentase } \\
(\%)\end{array}$ \\
\hline Kurang baik & 1 & 3,3 \\
Cukup baik & 19 & 63,3 \\
Baik & 10 & 33,3 \\
\hline \multicolumn{1}{c}{ Total } & 30 & 100 \\
\hline
\end{tabular}

Sumber : Data primer

Hasil penelitian menunjukan bahwa dari total 30 responden, dapat dilihat dalam kategori perilaku dalam pemakaian APD yaitu sebagian besar 19 responden $(63,3 \%)$ perilaku cukup baik, hampir setengahya 10 responden $(33,3 \%)$ perilaku baik, dan sebagian kecil 1 responden (33\%) perilaku kurang baik. Perilaku adalah merupakan totalitas penghayatan dan aktivitas seseorang, yang merupakan hasil bersama atau resultan antara berbagai faktor, baik faktor internal maupun eksternal. Benyamin Bloom membagi perilaku manusia ke dalam 3 domain yaitu kognitif, afektif, Psikomotor (Notoatmojo,2014). Didukung penelitian Nurmalia, Ulliya, Neny, Hartanty (2019) menunjukkan bahwa sebanyak 54,39\% tindakan yang dilakukan perawat tidak sesuai dalam penggunaan sarung tangan. Asumsi peneliti hal ini disebabkan karena perilaku saat memakai APD kurang didukung oleh sikap yang positip dan ketrampilan yang baik.

\section{Tabel 3}

Distribusi Frekuensi Tingkat Pengetahuan Perawat Dalam Pemakaian APD di Unit Rawat Inap Salah Satu Rumah Sakit Swasta di Yogyakarta

\begin{tabular}{ccc} 
& Februari 2021 \\
\hline Perilaku & $\begin{array}{c}\text { Frekuensi } \\
(\mathrm{n})\end{array}$ & $\begin{array}{c}\text { Persentase } \\
(\%)\end{array}$ \\
\hline Kurang baik & 5 & 16,7 \\
Cukup baik & 4 & 13,3 \\
Baik & 21 & 70 \\
\hline \multicolumn{1}{c}{ Total } & 30 & 100 \\
\hline
\end{tabular}

Sumber:Dataprimer

Hasil penelitian menunjukkan bahwa dari total 30 responden, dapat dilihat sebagian besar 21 responden (70\%) berpengetahuan baik, sebagian kecil pengetahuan 4 responden $(13,3 \%)$ cukup baik dan sebagian kecil 5 responden $16,7 \%$ kategori kurang baik. Menurut 
asumsi peneliti sebagian pelindung/celemek, masker, perisai wajah perawat mempunyai pengetahuan yang baik dikarenakan usia dari responden sebagian besar pada tahap dewasa awal, kemampuan kognitif individu berada dalam tahap prima karena individu mudah mempelajari, melakukan Penalaran logis, berfikir kreatif, dan belum terjadi penurunan kesehatan.

Tabel 4

Distribusi Frekuensi Sikap Perawat

Dalam Pemakaian APD di Unit Rawat Inap Salah Satu Rumah Sakit Swasta di Yogyakarta Februari 2021

\begin{tabular}{|c|c|c|}
\hline Perilaku & $\begin{array}{l}\text { Frekuensi } \\
\text { (n) }\end{array}$ & $\begin{array}{c}\text { Persentase } \\
(\%)\end{array}$ \\
\hline Negatif & 2 & 6,7 \\
\hline Cukup Positif & 16 & 53,3 \\
\hline Positif & 12 & 40 \\
\hline Total & 30 & 100 \\
\hline
\end{tabular}

Sumber:Dataprimer

Hasil penelitian menunjukkan

bahwa dari total 30 responden, dapat dilihat kategori sikap yaitu sebagian besar 16 responden $(53,3 \%)$ sikap cukup positip, hampir setengahnya 12 responden $(40 \%)$ sikap positip, dan sebagian kecil 2 responden.(6,7\%) sikap negatif. Sikap tentang pemakaian alat pelindung diri yaitu sikap merupakan tanggapan perawat terhadap pemakaian APD yang meliputi sarung tangan, gaun penutup kepala dan sepatu tertutup pada saat bekerja. Asumsi peneliti hal ini disebabkan karena perawat belum menyadari dengan baik pentingnya sikap dalam pemakaian APD. Didukung penelitian Simandalahi, Prawata \& Toruan (2018) perawat yang memiliki sikap negatif $73,3 \%$ dibandingkan perawat yang memiliki sikap positip 23,5\%. Sikap merupakan kesadaran dan kecenderungan untuk berbuat. Seorang tenaga kerja yang memiliki sikap baik diartikan sebagai seorang tenaga kerja memiliki kesadaran untuk berbuat baik.

Tabel 5

Distribusi Frekuensi Ketrampilan Perawat Dalam Pemakaian APD

Di Unit Rawat Inap Salah Satu Rumah Sakit Swasta di Yogyakarta Februari 2021

\begin{tabular}{ccc}
\hline Perilaku & $\begin{array}{c}\text { Frekuensi } \\
(\mathrm{n})\end{array}$ & $\begin{array}{c}\text { Persentase } \\
(\%)\end{array}$ \\
\hline Kurang baik & 5 & 16,7 \\
Cukup baik & 4 & 13,3 \\
Baik & 21 & 70 \\
\hline \multicolumn{1}{c}{ Total } & 30 & 100 \\
\hline
\end{tabular}

Sumber:Dataprimer

Dari hasil penelitian bahwa dari total 30 responden, dapat dilihat dalam kategori ketrampilan yaitu setengahnya 15 responden (50\%) ketrampilan cukup baik, hampir setengahnya 13 responden $(43,3 \%)$ ketrampilan baik dan sebagian kecil2 responden $(6,7 \%)$ kurang baik. Keterampilan secara sederhana yaitu 
Faktor yang Berhubungan dengan Perilaku Perawat dalam Pemakaian APD di Ruang Rawat Inap Salah Satu Rumah Sakit Swasta di Yogyakarta

kecakapan untuk menyelesaikan tugas (Sudarto, 2016). Hal ini juga didukung penelitan Wulandini \& Roza (2016) tindakan baik perawat dalam pemakaian APD sebesar 63,6\%.

\section{Tabel 6}

Hubungan Pengetahuan dengan Perilaku Perawat dalam Pemakaian Alat Pelindung Diri di Ruang Rawat Inap Salah Satu Rumah Sakit Swasta di Yogyakarta Februari 2021

\begin{tabular}{|c|c|c|c|c|c|}
\hline \multirow[t]{3}{*}{$\begin{array}{l}\text { Penge } \\
\text { tahuan }\end{array}$} & \multicolumn{4}{|c|}{$\begin{array}{c}\text { Perilaku Perawat dalam } \\
\text { Pemakaian APD }\end{array}$} & \multirow[t]{3}{*}{$\begin{array}{c}\mathrm{p}- \\
\text { value }\end{array}$} \\
\hline & \multicolumn{2}{|c|}{ Cukup baik } & \multicolumn{2}{|c|}{ Baik } & \\
\hline & $\mathrm{n}$ & $\%$ & $\mathrm{n}$ & $\%$ & \\
\hline Cukup & 8 & 26,66 & 1 & 3,3 & 0,204 \\
\hline baik & 12 & 40 & 9 & 30 & \\
\hline \multicolumn{6}{|l|}{ Baik } \\
\hline Total & 20 & 66,7 & 10 & 33,3 & \\
\hline
\end{tabular}

Didapatkan $p$-value 0,204 (>0,05) artinya $\mathrm{H} 0$ diterima dan $\mathrm{Ha}$ ditolak yaitu tidak terdapat hubungan yang signifikan antara tingkat pengetahuan dengan perilaku pemakaian APD. Dari analisis terdapat variabel pengetahuan tentang APD tidak membuktikan bahwa adanya hubungan yang signifikan terhadap perilaku pemakaian APD. Menurut teori Lawrence Green dalam Notoatmojo (2014) perilaku dipengaruhi oleh pengetahuan, kepercayaan, tradisi, sistem nilai masyarakat yang dapat mendorong atau menghambat perilaku. Penelitian
Mariana(2017) dalam penelitian Wapah \& Wijaya (2020) berdasarkan hasil peneliltian menggunakan ChiSguare ditemukan nilai $\mathrm{p}(0,099)$ yang artinya tidak ada hubungan antara pengetahuan dan penggunaan APD.

Tabel 7

Hubungan Sikap dengan Perilaku Perawat dalam Pemakaian Alat Pelindung Diri di Ruang Rawat Inap Salah Satu Rumah Sakit Swasta di Yogyakarta Februari 2021

\begin{tabular}{|c|c|c|c|c|c|}
\hline \multirow[t]{3}{*}{ Sikap } & \multicolumn{4}{|c|}{$\begin{array}{c}\text { Perilaku Perawat dalam } \\
\text { Pemakaian APD }\end{array}$} & \multirow[t]{3}{*}{$\begin{array}{c}\mathrm{p}- \\
\text { value }\end{array}$} \\
\hline & \multicolumn{2}{|c|}{ Cukup baik } & \multicolumn{2}{|c|}{ Baik } & \\
\hline & $\mathrm{n}$ & $\%$ & $\mathrm{n}$ & $\%$ & \\
\hline Cukup & 16 & 53,33 & 2 & 6,5 & 0,004 \\
\hline baik & 4 & 13,33 & 8 & 26,6 & \\
\hline \multicolumn{6}{|l|}{ Baik } \\
\hline Total & 20 & 66,7 & 10 & 33,3 & \\
\hline
\end{tabular}

Pada uji hipotesi sFisher'sExact Test didapatkan p-value $0.004(<0,05)$ artinya H0 ditolak dan Ha diterima yaitu terdapat hubungan yang signifikan antara sikap dengan perilaku pemakaian APD. Hal ini didukung penelitian Repi, Josephus \& Rattu (2016) sikap positip perawat dalam pemakaian APD $50 \%$, sikap negatif 50\% dengan nilai $\mathrm{p} p$ value 0,000 yang artinya ada hubungan antara sikap dengan pemakaian APD. Menurut teori Bloom dalam Notoatmojo (2014) sikap belum merupakan suatu tindakan atau aktivitas, akan tetapi merupakan presdiposisi tindakan suatu perilaku. Pada sikap ada 
berbagai tingkatan dan sikap kesehatan kemudian melaksanakan pemakaian APD pada tingkat atau mempraktikan apa yang diketahui menerima, merespon, menghargai atau disikapinya (dinilai baik). Menurut serta bertanggung jawab. Hal ini Notoatmojo (2014) praktik ini sesuai dengan bagian lain Alpor $\mathrm{t}$ mempunyai beberapa tingkatan yaitu (1945) dalam Notoatmojo (2014) sikap mempunyai 3 komponen pokok yaitu kepercayaan, kehidupan emosional, kecenderungan untuk bertindak terhadap suatu obyek.

Tabel 8

Hubungan Ketrampilan dengan Perilaku Perawat dalam Pemakaian Alat Pelindung Diri di Ruang Rawat Inap Salah Satu Rumah Sakit Swasta di Yogyakarta Februari 2021

\begin{tabular}{|c|c|c|}
\hline \multirow[t]{2}{*}{$\begin{array}{l}\text { Ketra } \\
\text { mpilan }\end{array}$} & $\begin{array}{c}\text { Perilaku Perawat dalam } \\
\text { Pemakaian APD }\end{array}$ & \multirow[t]{2}{*}{$\begin{array}{c}\text { p- } \\
\text { value }\end{array}$} \\
\hline & Cukup baik & \\
\hline
\end{tabular}

\begin{tabular}{clcccc} 
& $\mathrm{n}$ & $\%$ & $\mathrm{n}$ & $\%$ & \\
\hline Cukup & 16 & 53,33 & 1 & 3,3 & 0,000 \\
baik & 4 & 13,33 & 9 & 30 &
\end{tabular}
Baik

\begin{tabular}{ccccc}
\hline Total & 20 & 66,7 & 10 & 33,3 \\
\hline Sumber:Dataprimer
\end{tabular}

Berdasarkan uji hipotesis Fisher's Exact Test didapatkan $p$ value $0,000 \quad(<0,05)$ artinya $\mathrm{H} 0$ ditolak dan Ha diterima yaitu terdapat hubungan yang signifikan antara tingkat ketrampilan dengan perilaku pemakaian APD.mempunyai perilaku baik. Menurut Bloom dalam Notoatmojo (2014) praktik atau tindakan adalah setelah seseorang mengetahui stimulus atau obyek respon terpimpin, mekanisme dan adopsi. Hal ini didukung penelitian Mariana ( 2017 ) dalam Wapah dan Wijaya (2020) ada hubungan antara tindakan dengan penggunaan APD pada perawat dengan nilai $\rho(0,000)$.

\section{KESIMPULAN DAN SARAN}

Berdasarkan uraian dari data diatas dapat ditarik kesimpulan diantaranya adalah tidak terdapat hubungan yang signifikan antara tingkat pengetahuan dengan perilaku perawat dalam pemakaian APD dengan $p$ - value $0,004(<0,05)$ terdapat hubungan yang signifikan antara sikap dengan perilaku perawat, dalam pemakaian APD dengan $p$ - value $0,004(<0,05)$, terdapat hubungan yang signifikan antara ketrampilan dengan perilaku perawat dalam pemakaian APD dengan $p$-value $0,000(<0,05)$. Disarankan bagi peneliti lain dapat meneliti faktor-faktor yang berhubungan dengan perilaku pemakaian APD dalam bentuk penelitian kualitatif agar dapat menggali fenomena yang terjadi pada 
V.Endah Mawarni, Ch. Setya Widyastuti, Eva Marti Faktor yang Berhubungan dengan Perilaku Perawat dalam Pemakaian APD di Ruang Rawat Inap Salah Satu Rumah Sakit Swasta di Yogyakarta

perawat dalam pemakaian APD.

\section{DAFTARPUSTAKA}

Apriluana,G.,Khairiyati,L.,\&S

etyaninrum, R. (2016).

Hubungan antara

usia,jeniskelamin,lama

kerja, pengetahuan,sikap

dan ketersediaan alat

pelindung diri(APD)

dengan perilaku

penggunaanAPD pada

tenaga kesehatan. $(3, \mathrm{Ed}$.

Jurnal

Publikasi

Kesehatan Masyarakat

Indonesia, 3,82-87.

Kemetrian Kesehatan Republik Indonesia. (2020). Petunjuk Tehnis Alat Pelindung Diri (APD)

Dalam Menghadapi Virus

Corona. Direktorat

Jenderal Kefarmasian dan

Alat Kesehatan. Jakarta

Selatan.

Lubis,N.A.(2020). Faktor yang mempengaruhi kecemasan pada tenaga kesehatan dalam upaya pencegahan covid-19. Preprints , 1-7.Doi :htt doi.org/10.31219/osf.io/srhvz
Mahmood S, Crimbly F, Khan S, Mehwis.(May23,2020)Strategiesf orRational Use of Personal Protective Equipment (PPE) Among Health care Providers During the COVID-19 Crisis. Cureus12 (5): e8248.DOI $10.7759 /$ cureus. 8248

Notoatmodjo,S.(2014).Promosi Kesehatan Dan Perilaku Kesehatan. Jakarta: RinekaCipta.

Nurmalia, D., Ulliya, S., \& Hartanty, A. A.(2019). Gambaran penggunaan alat perlindungan diri oleh perawat diruang perawatan rumah sakit. Journal of Holistic Nursing and Health Science, 2 (1), $45-53$

Simandalahil,T.,Marda,A.H.,\&Ang graeni,E.N.(2018).Faktor yang berhubugan dengan pelaksanaan universal precautions diinstalasi gawat darurat.JurnalIlmuKesehatan, 3(2),108-117.Doi: $10.33757 /$ jik.v3i2.23

Theopilus, Y., Thedy, Y., Theresia, C.,\&Octavia,R.J.(2020). Analisis risiko produk Alat pelindung diri(APD) pencegah 
Jurnal Keperawatan I CARE, Vol. 2 No. 2 Tahun 2021

$\begin{array}{lr}\text { penularan } & \text { COVID-19 } \\ \text { untuk pekerja } & \text { informal } \\ \text { diIndonesia. } & \text { Jurnal }\end{array}$

Rekayasa Sistem Industri , 9

(2),

115Doi:https://doi.org/10.2

6593/jrsi.v9i2.4002.

Wapah,W.,\&Wijaya,L.(2020).L

iteratur review: Hubungan

pengetahuan dengan

kepatuhan perawat dalam

penggunaan alat

perlindungan diri dasar

Jurnal Ilmiah Multi

Science

Kesehatan,12(2).,126-139 